CASSOWARY Volume 2 (2): 128 - 146

ISSN : 2614-8900

E-ISSN : 2622-6545

CProgram Pascasarjana Universitas Papua, https://pasca.unipa.ac.id/

\title{
Kajian pemanfaatan ruang kawasan pesisir studi kasus kawasan permukiman kumuh Kelurahan Padarni Kabupaten Manokwari
}

\author{
Study of coastal area space use: case study of slum areas of Padarni Village, \\ Manokwari Regency
}

Adityo Dwi Nugroho

Program Studi Magister Ilmu Lingkungan, Program Pascasarjana, Universitas Papua

Email: adhitphiko@gmail.com

\begin{abstract}
Manokwari is a coastal city and the capital city of the Province which is considered as very strategic and growing city, making Manokwari more attract for jobs seeker. Many low- income people who migrate to Manokwari make densely populated and slum squatter settlements inevitable. Padarni Coastal Area is one of the urban areas with very poor environmental conditions, Irregular, disaster-prone settlements as well as basic facilities and infrastructure have not been realized properly so that the community cannot move and live properly. The results of the study were 6 causes of slum conditions: Socio-cultural Characteristics, level of urbanization, limited land, accessibility, facilities and infrastructure, and weak of government policies. With the concept of waterfront development, settlement arrangement activities are directed at the utilization of local potential, phasing improvement in the quality of settlements and sustainable slums prevention.
\end{abstract}

Keywords: Coastal Settlement, Slum Area, and Arrangement of region

ABSTRAK: Manokwari adalah kota pesisir dan ibu kota Provinsi yang dianggap sangat strategis dan berkembang, membuat Manokwari lebih menarik bagi pencari kerja. Banyak orang berpendapatan rendah yang bermigrasi ke Manokwari membuat pemukiman padat dan pemukiman kumuh tak terhindarkan. Wilayah Pesisir Padarni adalah salah satu daerah perkotaan dengan kondisi lingkungan yang sangat buruk, permukiman yang tidak teratur, rawan bencana serta sarana dan prasarana dasar belum terealisasi dengan baik sehingga masyarakat tidak dapat bergerak dan hidup dengan baik. Hasil penelitian adalah 6 penyebab kondisi kumuh: Karakteristik Sosial-budaya, tingkat urbanisasi, keterbatasan lahan, aksesibilitas, fasilitas dan infrastruktur, dan lemahnya kebijakan pemerintah. Dengan konsep pengembangan tepi laut, kegiatan pengaturan permukiman diarahkan pada pemanfaatan potensi lokal, secara bertahap meningkatkan kualitas permukiman dan pencegahan permukiman kumuh yang berkelanjutan.

Keywords: Permukiman pesisir, area kumuh, tata ruang 


\section{PENDAHULUAN}

Pada tahun 2016 masih terdapat 35.291 Ha permukiman kumuh perkotaan yang tersebar di hampir seluruh wilayah Indonesia sesuai hasil perhitungan pengurangan luasan permukiman kumuh perkotaan yang dilaksanakan oleh Direktorat Jenderal Cipta Karya (KEMENPUPERA, 2016). Kondisi ini disebabkan perubahan struktur kota, pertumbuhan penduduk, pengendalian bangunan yang lemah serta semakin meningkatnya kebutuhan penduduk akan hunian mengakibatkan pertumbuhan pemukiman di berbagai wilayah meningkat, termasuk juga pembangunan di kawasan yang tak layak huni menjadi hal yang tidak terhindarkan.

Dengan jumlah penduduk 8.262 jiwa (BPS, 2017) dan luas wilayah sekitar $65 \%$ merupakan lahan terbangun (Profil Kelurahan Padarni Tahun 2016), Kelurahan Padarni merupakan bagian dalam pusat pengembangan kota Manokwari memiliki berbagai permasalahan kota seperti hunian padat, kumuh dan hunian liar, penyimpangan lahan serta menurunnya kualitas lingkungan utamanya pada kawasan pesisir pantai.

Beberapa dampak dari penyimpangan penggunaan lahan kawasan Pesisir antara lain, rusaknya vegetasi Pantai, munculnya genangan air, menurunnya kualitas air, berkurangnya lahan non terbangun, dan berubahnya struktur mata pencaharian asli, terjadi kepadatan dan ketidakteraturan bangunan karena terbatasnya ruang, tidak ada atau terbatasnya ruang terbuka hijau sebagai daerah resapan hujan dan pengurang polusi udara, aksesibilitas terbatas pada pemukiman padat penduduk, penyempitan ruang terbuka karena banyak dijadikan pemukiman, akses untuk mendapatkan air bersih dan air minum yang layak sulit didapat, tidak adanya drainase yang baik dapat menyebabkan banjir pada saat musim penghujan (Firmansyah, 2013).

Arahan dalam penataan ruang Kabupaten Manokwari yang tidak secara spesifik mengarahkan penataan ruang pada kawasan pesisir terutama Kelurahan Padarni baik melalui produk turunan penataan ruang, sehingga pada prosesnya dapat menyebabkan partumbuhan dan peralihan penggunaan menjadi tidak terkontrol bahkan dapat menyebabkan degradasi lingkungan kawasan pesisir.

\section{METODE PENELITIAN}

Penelitian ini bermaksud menggambarkan kondisi penggunaan lahan pesisir Kelurahan Padarni berdasarkan karakteristik spasial, disesuaikan dengan kebijakan penataan wilayah (tata ruang) berdasarkan kecenderungan pola perubahan penggunaan ruang serta kondisi kekumuhan. Dilakukan pemeriksaan yang mendalam terhadap suatu keadaan atau kejadian yang disebut sebagai kasus (dalam hal ini kondisi kekumuhan di Kawasan Pesisir kelurahan Padarni) dengan menggunakan cara-cara yang sistematis dalam melakukan pengamatan, pengumpulan data, analisis informasi, dan pelaporan hasilnya. Sebagai hasilnya, akan diperoleh pemahaman yang mendalam tentang mengapa sesuatu terjadi dengan menggambarkan dan menjelaskan hubungan/gejala yang ada (Prasetyo, 2006).

Tujuan yang ingin dicapai adalah:

1. Mengidentifikasi pemanfaatan lahan di kelurahan Padarni dengan mengkaji pola penggunaan lahan wilayah kelurahan Padarni,

2. Mengidentifikasi perubahan penggunaan lahan, kecenderungan perubahan penggunaan lahan wilayah pesisir, dan penyebab yang mendorong kondisi kekumuhan kelurahan Padarni. 
3. Memberikan arahan Peningkatan kualitas Kawasan Permukiman Kumuh Kelurahan Padarni.

Penelitian dilaksanakan Selama kurang lebih 2 (Dua) Bulan, mulai dari Bulan Desember 2017 sampai dengan bulan Januari 2018. Adapun lingkup lokasi adalah Kelurahan Padarni Distrik Manokwari Barat dengan luas wilayah sebesar 56,5 Ha dan fokus pada kawasan pesisir Angrem dan Borobudur. Pertimbangan peneliti dalam memilih lokasi karena lokasi merupakan Kawasan untuk hunian serta okupasi wilayah perairan untuk bangunan hunian.

\section{Populasi dan Sampel}

Dengan tingkat nilai kritis yang diinginkan yaitu sebesar 10\%, ditentukan jumlah sampel dengan menggunakan rumus Slovin (Sugiyono, 2010):

$$
\eta=\frac{N}{1+\left(N X e^{2}\right)}
$$

y : Jumlah elemen atau anggota Sampel

$\mathrm{N}$ : Jumlah elemen (anggota Populasi)

e : error level (tingkat kesalahan 10 $\%$ atau 0,1$)$

Jumlah populasi yang dimaksud adalah jumlah kepala rumah tangga (KRT) yang menempati Kawasan Pesisir kelurahan Padarni dengan batasan Wilayah administrasi Rukun Tetangga (RT).

$$
\begin{gathered}
=\frac{704}{1+\left(704 \times 10 \% 0^{2}\right.}=\frac{704}{8,04} \\
=87 \mathrm{KRT}
\end{gathered}
$$

Pemilihan KRT sebagai responden penelitian karena berdasarkan hasil prasurvey ditemukan pada bebe-rapa rumah terdapat lebih dari $1 \mathrm{KK}$. Pengambilan sampel secara proporsi dilakukan dengan mengambil subyek dari setiap strata atau setiap wilayah ditentukan seimbang dengan banyaknya subyek dalam masing-masing strata atau wilayah (Arikunto, 2006). Wilayah yang dimaksud yaitu Rukun Tetangga (RT). Kemudian dilakukan teknik Systematic Sampling (sampling sistematis) yaitu pengambilan sampel secara acak sistematis, teknik ini menggunakan daftar penduduk pada masing strata/wilayah RT yang dipilih berdasarkan interval tertentu, besaran interval disesuaikan dengan jumlah sampel dan populasinya (sugiyono, 2010).

Adapun besar sampel untuk masing-masing RT dengan mengunakan rumus menurut Sugiyono (2010).

$$
n=\frac{x}{N} N_{1}
$$

Keterangan:

y : Jumlah sampel yang diinginkan setiap RT

$\mathrm{N}$ : Jumlah seluruh populasi di

Kawasan Pesisir Kelurahan

Padarni (704 KRT)

$\mathrm{x} \quad$ : Jumlah populasi KRT pada setiap RT N1 : Jumlah populasi Sampel ( $87 \mathrm{KRT}$ )

Permukiman yang teridentifikasi kumuh wilayah dengan keragaman penggunan lahan, intensitas perubahan penggunaan lahan/alih fungsi lahan yang signifikan terutama pada lahan tak terbangun/kawasan pesisir sebagai dampak dari meningkatnya kegiatan dan pembangunan lahan

Jumlah Interval Pengambilan sampel (k) adalah:

$$
\mathrm{K}=\mathrm{N} / \mathrm{n}=704 / 87=8
$$

Prioritas populasi yang menjadi kajian yaitu warga yang menempati 
kawasan pesisir di wilayah kelurahan Padarni. Berdasarkan Data kependudukan tahun 2016, jumlah penduduk Kelurahan Padarni sejumlah 7.419 jiwa, Jumlah Kepala Keluarga (KK) 1.454 KK, dan kepala rumah tangga (KRT) 1.115 KRT yang tersebar dalam 7 RW dan 25 RT (Profil Kelurahan Padarni Tahun 2016). Sedangkan untuk fokus lokasi penelitian yaitu kawasan pesisir jumlah penduduk adalah 3.110 jiwa yang tersebar di 13 RT.

\section{Prosedur Penelitian}

Tahapan Persiapan berupa:

a. Menentukan daerah penelitian dan obyek- obyek yang akan dikaji.

b. Mencari referensi untuk studi pustaka mengenai pemanfaatan ruang kawasan pesisir permukiman, indikator kekumuhan dan berbagai bahasan lain yang sesuai.

c. Menentukan parameter-parameter yang dibutuhkan dalam pemanfaatan ruang kawasan pesisir.

d. Menentukan metode dan titik sampel yang digunakan dalam penelitian. Pengambilan sampel dilakukan dalam penelitian adalah metode Systematic Random Sampling. Pengambilan sampel pada penelitian ini dimaksudkan untuk efisiensi biaya, waktu, dan tenaga.

e. Membuat peta Tematik mengenai variabel amatan

f. Mempersiapkan alat dan bahan yang dibutuhkan dalam penelitian.

Data yang dipergunakan merupakan data sekunder dan primer. Data primer diperoleh dari observasi awal dan survey sekunder yaitu studi kepustakaan, dan sumber-sumber lainnya. Kegiatan survey lapangan (pengambilan data primer) selain dimaksudkan untuk pengambilan data, juga dilakukan untuk menguji ketelitian/kesesuaian hasil interpretasi dengan kondisi di lapangan dan untuk menilai variabel amatan yang diinginkan serta variabel yang tidak dapat diperoleh dari citra dan peta. Metode- metode kerja lapangan yaitu metode dokumentasi, observasi, dan juga wawancara.

\section{Analisis Data}

\section{Deskripsi Statistik Dengan Metode Distribusi}

\section{Frekuensi Relatif (Persen \%)}

Pada analisis deskriptif ini, akan dikemukakan cara-cara penyajian data, salah satunya menggunakan tabel distribusi frekuensi. Analisis ini dilakukan pada variabel kependudukan baik pada kompisisi penduduk maupun karakteristiknya, komposisi penggunaan lahan, indikator-indikator kumuh, serta variabel- variabel amatan lainnya Dari hasil yang diperoleh, data kemudian dikelompokkan ke dalam beberapa varibel dengan maksud agar ciri- ciri penting data tersebut dapat segera terlihat.

\section{Analisis Penggunaan Lahan}

Dilakukan untuk mengidentifikasi pola penggunaan lahan dengan bantuan perangkat lunak ArcGIS 10. Hasil analisis berupa: Peta gambaran umum kawasan, peta pola penggunaan lahan, yang menggambarkan penggunaan lahan existing wilayah studi, Peta kesesuaian penggunaan lahan, yang menggambarkan sebaran penyimpangan lahan, dan peta tematik lainnya. Berikut adalah analisis penggunaan lahan yang dilakukan:

1. Analisis Pemanfaatan Ruang Wilayah, dilakukan dengan menganalisis penggunaan lahan eksisting di wilayah Kelurahan Padarni.

2. Analisis Perubahan Penggunaan Lahan, dilakukan dengan menganalisis perubahan (bentuk dan pola) penggu- 
naan lahan yang ada berdasarkan tahun penggunaan lahan tersebut. Perubahan penggunaan lahan selain dikaji secara spasial, juga di lihat dari motivasi perubahannya berdasarkan keterangan responden dengan hasil analisis berupa gambaran kecenderungan perubahan lahan.

3. Analisis kesesuaian penggunaan lahan, dilakukan dengan membandingkan arahan penggunaan lahan sesuai kebijakan daerah terhadap kondisi existing penggunaan lahan (peta arahan dan peta eksisting)

Analisis Kondisi Kekumuhan dan faktor pendorong kondisi kekumuhan, Dilakukan melalui kajian indikatorindikator kekumuhan sesuai Permen PUPERA No. 2 tahun 2016.

\section{HASIL DAN PEMBAHASAN}

\section{Gambaran Wilayah}

Kelurahan Padarni memiliki topografi berupa dataran rendah pada bagian tengah dan pantai/pesisir (pada bagian Barat) sampai dengan berbukit pada bagian Timur. Ketinggian rata-rata 1-3 mdpl pada pesisir dan 4-10 mdpl pada daerah bukit, Keseluruhan wilayah didominasi dengan penggunaan lahan terbangun dengan jenis bangunan permanen, mayoritas berada di daerah dataran rendah seperti di jalan Merdeka dan jalan Sudirman. Termasuk dalam Pusat Pelayanan Primer dan wilayah pengembangan kawasan perkotaan yang berperan sebagai Ibu Kota Kabupaten Manokwari dan memiliki fungsi sebagai pusat pelayanan skala kabupaten yang meliputi : pusat pelayanan pemerintahan, pendidikan dan kesehatan skala Kabupaten Manokwari.

\section{Penduduk}

Secara keseluruhan di Padarni jumlah penduduk mencapai 8.262 jiwa
(BPS, 2017) dengan Jumlah Rumah Tangga 1.921 RT. Jumlah penduduk padarni merupakan urutan ke 5 terbanyak di Distrik Manokwari Barat namun dengan kepadatan tertinggi kedua dengan 587,62 penduduk perkm2, menempati urutan kedua setelah Kelu-rahan Wosi. Sebagian besar beragama Kristen Protestan kemudian disusul agama Islam. Data Dinas Dukcapil 2015, pekerjaan penduduk sebagian besar (30\%) merupakan buruh dan wiraswasta. Kondisi ini tidak terlepas dari banyaknya aktifitas perdagangan dan perkantoran serta sektorsektor jasa lainnya disekitar kelurahan padarni. Pada komposisi penduduk menurut pendidikan, sebagian besar warga Padarni merupakan tamatan SLTA atau sederajat yaitu berjumlah 5.061 jiwa. Daerah Padarni terutama pada kawasan kumuhnya sebagian besar warganya merupakan pekerja swasta, buruh atau nelayan.

\section{Daya dukung lahan}

Daya dukung lahan dihitung dari kebutuhan lahan per jiwa. Daya dukung lahan dapat diketahui melalui perhitungan daya tampung lahan. Nilai yang didapat dari hasil perhitungan daya tampung dapat digunakan sebagai acuan untuk mengetahui kawasan mana saja yang berada pada kondisi ambang batas yang masih dapat dimanfaatkan (Suryanto, 2009). Dari hasil perhitungan hanya RT 2 RW 2 yang masih mendukung untuk pengembangan meskipun sudah mendekati batasan daya dukung lahan, sedangkan untuk kondisi terendah atau sudah sangat tidak mendukung adalah di RT 5 RW 3, RT2 RW3 dan RT3 RW3.

\section{Ekonomi dan Sosial}

Seperti pada wilayah pesisir lainnya, kawasan Padarni Pantai merupakan permukiman dengan mayoritas penduduk sebagai, pedagang. pekerja 
swasta dan nelayan. Dengan ketergantungan terhadap hasil laut di sekitar wilayah kota Manokwari, nelayan pesisir padarni memiliki pendapatan yang relatif rendah. Hasil tangkapan yang diperoleh dari sekitar laut kota Manokwari dijual di pasar Ikan Sanggeng dan pasar Borobudur. Selain perikanan, terdapat juga pelabuhan perintis/feri Angrem sebagai pusat kegiatan masyarakat dan menggerakan kegiatan ekonomi daerah sekitarnya. Jenis pekerjaan responden paling banyak berprofesi sebagai nelayan (35 Orang) disusul sektor swasta 25 orang dan yang paling sedikit adalah pensiunan PNS.

Secara kemampuan ekonomi, sekitar 78\% (876) kepala rumah tangga di Kelurahan Padarni termasuk dalam masyarakat berpenghasilan rendah (Profil Kelurahan Padarni Tahun 2016). Masyarakat Berpenghasilan Rendah (MBR) adalah masyarakat yang mempunyai keterbatasan daya beli sehingga perlu mendapat dukungan pemerintah untuk memperoleh rumah (UndangUndang No. 1 Tentang Perumahan dan Kawasan Permukiman, 2011). MBR di lokasi penelitian paling banyak terdapat di wilayah RT 05 RW 03 sebanyak 153 KRT.

Terdapat lebih dari 15 etnis yang mendiami kawasan Padarni (RPLP Padarni, 2015), hal tersebut merupakan ciri dari kawasan di Manokwari yang telah berkembang cukup lama. Toleransi yang baik menjadikan kondisi sosial yang ada sangat mendukung perkembangan kawasan. Kondisi masyarakat yang heterogen merupakan potensi yang terdapat di kelurahan ini terlihat dari berbagai kegiatan budaya lokal seperti acara adat, tari-tarian, ukiran dan seni lain. Kondisi budaya/etnis ini juga yang mempengaruhi pola pemanfaatan ruang kawasan seperti misalnya pembangunan rumah sederet dalam satu marga (berhubungan keluarga), pengelolaan tanah adat dan lain sebagainya.

\section{Analisis Penggunaan Lahan dan Bangunan}

Sebagian besar penggunan lahan di kelurahan Padarni merupakan lahan terbangun, yaitu sebesar $97 \mathrm{Ha}$ atau sekitar $78 \%$ dari total luas keseluruhan wilayah (PNPM, 2015). sebagian besar merupakan bangunan dengan fungsi hunian disusul oleh bangunan untuk perkantoran serta perdagangan dan jasa serta lainnya. Pertumbuhan peralihan penggunaan lahan dari lahan tak terbangun menjadi lahan terbangun sebagian besar terjadi di wilayah bagian Timur dan Barat sedangkan untuk jalan serta Ruang terbuka hijau/publik relatif tetap. Mayoritas bangunan bentuk kapling tidak beraturan, begitu pula arah hadap bangunan responden yang terdapat di daratan mayoritas menghadap ke arah jalan lingkungan, bangunan yang berada di tepian (talud) juga menghadap kearah daratan, dan untuk bangunan yang berada di atas air arah hadap bangunan mengikuti/menghadap kearah jembatan titian.

Sebanyak 79 responden memiliki bangunan dengan fungsi hunian sedangkan 8 responden memiliki bangunan dengan fungsi campuran huni-an, perdagangan dan jasa tanpa merubah fungsi utama bangunan yaitu hunian. Secara umum kawasan kumuh merupakan kawasan hunian dengan tingkat kepadatan yang tinggi dan dihuni oleh masyarakat miskin (Sadana, 2014). Sesuai arahan dalam peraturan bangunan gedung Kabupaten Manokwari, setiap bangunan umum apabila tidak ditentu-kan lain, ditentukan KDB maksimum 60\% dari luas area bangunan (Peraturan Daerah Kab Manokwari No 10 tahun 2003 tentang Bangunan Gedung). Berdasarkan hasil survey, kepadatan rata-rata 
bangunan daratan di kawasan pesisir adalah $83 \%$.

Dengan rata-rata luasan bangunan rata- rata $73 \mathrm{~m} 2$, bangunan di lokasi studi sebagian besar belum memenuhi standar yang baik. Merujuk pada SNI 031733-2004 tentang tata cara perencanaan lingkungan perumahan, standar kebutuhan hunian layak huni untuk 1 keluarga (5 orang) dengan perhi-tungan kebutuhan luas latai 1 keluarga minimum adalah $51 \mathrm{~m} 2$, maka jumlah rumah yang tidak layak huni di wilayah studi masih terdapat 23 bangunan atau $26 \%$ dari populasi responden. Sedang-kan terdapat 32 bangunan (37\%) bangunan berukuran 51-100 m2 dan ukuran bangunan diatas $100 \mathrm{~m} 2$ sebanyak 32 bangunan.

\section{Perubahan Penggunaan Lahan/Ba- ngunan}

Sebanyak $36(41 \%)$ responden membangun sendiri bangunannya, sedangkan sebanyak $32 \%$ (28 responden) memperolehnya dari warisan keluarga. Dari 36 responden yang membangun bangunannya sendiri, 25 diantaranya merupakan bangunan dengan jenis bangunan rumah panggung dan dibangun di atas air/tepi air.

Motivasi perubahan lahan/ bangunan Terdapat 3 pola utama perubahan penggunaan lahan yang dipengaruhi aspek sosial:

\section{Sistem Kekerabatan}

Dengan berkembangnya penduduk dan juga kemajuan jaman, terjadi pergeseran bentuk rumah dan tata letak bangunan di wilayah pesisir. Dulu rumah mempunyai bentuk melebar, saat ini rumah memanjang dari daratan ke arah laut. Hal ini disebabkan adanya pembagian lahan dan waris bagi keturunan dari pemilik rumah. Hubungan kekerabatan akhirnya membentuk permukiman di wilayah ini. Ditandai dengan adanya hubungan kekerabatan antar satu rumah dengan rumah yang lain yang berdekatan. Atau antara kerabat, rumahnya saling bersebelahan.

\section{Rasa Kesukuan/satu kampung halaman}

Merupakan penggunaan lahan kelompok-kelompok tertentu yang membentuk hunian bersama karena berasal dari daerah yang sama yang memiliki hubungan keluarga maupun tidak. Pola membangun lahan adalah orang yang lebih dulu datang membangun bangunan kemudian disusul orang baru berikutnya yang membangun di sebelahnya mengikuti pola sebelumnya. Model kepemilikan bisa berupa warisan, jual beli, atau membangun sendiri karena kondisinya adalah wilayah perairan. Seperti wilayah RW 3, RW 4 dan RW 5.

\section{Nonkekerabatan}

Hubungan Nonkekerabatan, adalah keluarga tidak memiliki hubungan kekerabatan dengan tetangga sekitar dan berbagi kapling tanah. Dimana pemilik tanah menerima pendatang yang berasal dari luar bukan berdasarkan pertimbangan kekeluargaan namun memiliki pertimbangan lain seperti motif ekonomi yaitu sewa dan jual beli atau pemberian/hibah.

\section{Bentuk perubahan bangunan/lahan}

Terdapat 22 responden yang melakukan perubahan pada bangunan dari bentuk awal didirikan. Sebagian besar yaitu 9 responden merubah/ menambah ruangan kamar untuk memenuhi kebutuhan ruang kamar. Sebanyak 21 responden mengungkapkan motivasi perubahan bangunan adalah karena kebutuhan akan ruang tambahan dan 1 responden karena alasan ada lahan kosong. 
Kesesuaian penggunaan lahan

Dari keseluruhan RT diwilayah Pesisir Padarni, Hanya wilayah RT 03 RW 05 yang sesuai dengan arahan peruntukan lahan yaitu Zona campuran, sedangkan wilayah RT lainnya ada yang menempati sub zona sempadan pantai.
Luas ketidaksesuaian/penyimpangan lahan tertinggi berada di wilayah RT 05 RW 03 mencapai 90\% dari total luas wilayah RT yaitu 0,73 Ha. Kemudian yang kedua adalah wilayah RT $02 \mathrm{RW}$ 03 sebesar $81 \%$ (0,56 dari $0,69 \mathrm{Ha})$ dari total luasan.

Tabel 1. Kesesuaian Lahan Kawasan Pesisir

\begin{tabular}{|c|c|c|c|}
\hline RT-RW & $\begin{array}{c}\text { luas wilayah } \\
\text { (Ha) }\end{array}$ & $\begin{array}{c}\text { Luas Ketidaksesuaian } \\
\text { Lahan (Ha) }\end{array}$ & Persentase \\
\hline RT001-RW001 & 1,44 & 0,93 & $64 \%$ \\
\hline RT001-RW003 & 1,44 & 0,75 & $52 \%$ \\
\hline RT001-RW005 & 1,80 & 0,46 & $26 \%$ \\
\hline RT002-RW001 & 2,26 & 0,97 & $43 \%$ \\
\hline RT002-RW003 & 0,69 & 0,56 & $81 \%$ \\
\hline RT002-RW004 & 1,18 & 0,49 & $42 \%$ \\
\hline RT002-RW005 & 1,10 & 0,46 & $42 \%$ \\
\hline RT003-RW003 & 1,00 & 0,58 & $58 \%$ \\
\hline RT003-RW004 & 1,39 & 0,99 & $71 \%$ \\
\hline RT003-RW005 & 0,84 & 0,00 & $0 \%$ \\
\hline RT004-RW001 & 1,43 & 0,54 & $38 \%$ \\
\hline RT004-RW003 & 1,12 & 0,71 & $64 \%$ \\
\hline RT005-RW003 & 0,81 & 0,73 & $90 \%$ \\
\hline Jumlah/Rerata & 16,50 & 8,17 & $50 \%$ \\
\hline Hasil analisa, 2018 & & & \\
& & & \\
\hline
\end{tabular}

Tabel 1. Hasil Penilaian kondisi kekumuhan

\begin{tabular}{|c|c|c|c|c|c|c|c|c|c|c|}
\hline \multirow[t]{2}{*}{ No. } & \multirow[t]{2}{*}{ Lokasi } & \multicolumn{2}{|c|}{ Tingkat Kekumuhan } & \multicolumn{2}{|c|}{$\begin{array}{l}\text { Pertimbangan } \\
\text { Lain }\end{array}$} & \multirow{2}{*}{$\begin{array}{l}\text { Status } \\
\text { Lahan } \\
\text { Legal }\end{array}$} & \multirow{2}{*}{$\begin{array}{l}\text { Status } \\
\text { Lahan } \\
\text { Tidak } \\
\text { Legal }\end{array}$} & \multicolumn{2}{|c|}{$\begin{array}{c}\text { Penentuan } \\
\text { Klasifikasi } \\
\text { Kekumuhan }\end{array}$} & \multirow{2}{*}{$\begin{array}{c}\text { Skala } \\
\text { prioritas } \\
\text { Penanganan }\end{array}$} \\
\hline & & Nilai & Tingkatan & Nilai & Kriteria & & & Kelas & tingkatan & \\
\hline 1 & $\begin{array}{l}\text { RTO01- } \\
\text { RWO01 }\end{array}$ & 65 & Kumuh Sedang & 6 & Sedang & $(+)$ & & B3 & $\begin{array}{l}\text { Kumuh } \\
\text { Sedang }\end{array}$ & 5 \\
\hline 2 & $\begin{array}{l}\text { RTO01- } \\
\text { RWO03 }\end{array}$ & 79 & Kumuh Berat & 13 & tinggi & & $(-)$ & A2 & $\begin{array}{c}\text { Kumuh } \\
\text { Berat }\end{array}$ & 1 \\
\hline 3 & $\begin{array}{l}\text { RTO04- } \\
\text { RWO01 }\end{array}$ & 63 & Kumuh Sedang & 6 & Sedang & $(+)$ & & B3 & $\begin{array}{l}\text { Kumuh } \\
\text { Sedang }\end{array}$ & 5 \\
\hline 4 & $\begin{array}{l}\text { RTO04- } \\
\text { RW003 }\end{array}$ & 83 & Kumuh Berat & 13 & tinggi & & $(-)$ & A2 & $\begin{array}{c}\text { Kumuh } \\
\text { Berat }\end{array}$ & 1 \\
\hline 5 & $\begin{array}{l}\text { RTO02- } \\
\text { RWO01 }\end{array}$ & 49 & Kumuh Sedang & 11 & tinggi & $(+)$ & & B1 & $\begin{array}{l}\text { Kumuh } \\
\text { Sedang }\end{array}$ & 2 \\
\hline 6 & $\begin{array}{l}\text { RTO01- } \\
\text { RWO05 }\end{array}$ & 61 & Kumuh Sedang & 7 & Sedang & $(+)$ & & B3 & $\begin{array}{l}\text { Kumuh } \\
\text { Sedang }\end{array}$ & 5 \\
\hline 7 & $\begin{array}{l}\text { RTO02- } \\
\text { RWO03 }\end{array}$ & 79 & Kumuh Berat & 13 & tinggi & & $(-)$ & A2 & $\begin{array}{c}\text { Kumuh } \\
\text { Berat }\end{array}$ & 1 \\
\hline 8 & $\begin{array}{l}\text { RTO02- } \\
\text { RWO04 }\end{array}$ & 83 & Kumuh Berat & 11 & tinggi & & $(-)$ & A2 & $\begin{array}{c}\text { Kumuh } \\
\text { Berat }\end{array}$ & 1 \\
\hline 9 & $\begin{array}{l}\text { RTO02- } \\
\text { RWO05 }\end{array}$ & 82 & Kumuh Berat & 13 & tinggi & & $(-)$ & $A 2$ & $\begin{array}{c}\text { Kumuh } \\
\text { Berat }\end{array}$ & 1 \\
\hline $\begin{array}{l}1 \\
0\end{array}$ & $\begin{array}{l}\text { RTO03- } \\
\text { RWO03 }\end{array}$ & 85 & Kumuh Berat & 13 & tinggi & & $(-)$ & A2 & $\begin{array}{c}\text { Kumuh } \\
\text { Berat }\end{array}$ & 1 \\
\hline $\begin{array}{l}1 \\
1\end{array}$ & $\begin{array}{l}\text { RTO03- } \\
\text { RWO04 }\end{array}$ & 83 & Kumuh Berat & 10 & tinggi & & $(-)$ & A2 & $\begin{array}{c}\text { Kumuh } \\
\text { Berat }\end{array}$ & 1 \\
\hline $\begin{array}{l}1 \\
2 \\
\end{array}$ & $\begin{array}{l}\text { RTO03- } \\
\text { RW005 }\end{array}$ & 55 & Kumuh Sedang & 7 & Sedang & & $(-)$ & B4 & $\begin{array}{l}\text { Kumuh } \\
\text { Sedang }\end{array}$ & 5 \\
\hline $\begin{array}{l}1 \\
3\end{array}$ & $\begin{array}{l}\text { RTO05- } \\
\text { RWO03 }\end{array}$ & 89 & Kumuh Berat & 13 & tinggi & & $(-)$ & A2 & $\begin{array}{c}\text { Kumuh } \\
\text { Berat }\end{array}$ & 1 \\
\hline
\end{tabular}




\section{Analisis Kondisi Kekumuhan}

Analisis kondisi kekumuhan dilakukan dengan analisis meliputi 9 aspek utama. Hasil penilaian, terdapat 8 RT yang termasuk kategori kumuh berat dan sisanya 5 RT masuk dalam kategori kumuh sedang. Nilai kekumuhan 3 RT kategori sedang juga mendekati kategori kumuh berat.

Penyebab Kondisi Kekumuhan Pesisir Padarni Beberapa faktor yang menyebabkan kondisi kekumuhan diantaranya:

\section{Karakteristik Sosial budaya Penduduk}

Hubungan kekerabatan karena kesamaan daerah asal (kampung) umumnya masih terasa kental dbandingkan masyarakat perkotaan, karena umumnya suatu kesatuan permukiman yang sama sebagian besar dihuni oleh penduduk yang mempunyai pertalian darah. Makin bersifat kedesaan makin kental ciri-ciri kekerabatannya. Anggota keluarga yang kemudian membina rumah tangganya sendiri pada umumnya akan membangun tempat huniannya di sekitar rumah orang tuanya atau masih dalam satu unit permukiman yang sama (Yunus, 2008). Penduduk kawasan pesisir sebagian besar merupakan penduduk yang mendiami daerah pesisir/pantai juga di wilayah asalnya. Pola-pola pembagian lahan dan pengaturan/tata letak juga berhubungan dengan kebiasaan dari daerah asal responden.

\section{Faktor Urbanisasi atau Perpindahan Penduduk}

Keseluruhan responden kawasan pesisir Kelurahan Padarni merupakan pendatang yang berasal dari berbagai daerah, sebagian besar pemilik hak atas tanah adalah pemerintah daerah dan suku Mandacan sedangkan suku yang paling dominan mendiami kawasan pesisir adalah berasal dari Kabupaten Buton seperti daerah Barangka, Lombe (warga Borobudur 2 dan 4/RW

3) dan daerah Pulo Makasar Kota BauBau (Warga Borobudur 1/RW 4), suku Wondana di RW 1 dan 2 serta suku biak di wilayah RW 5. Dengan meningkatnya jumlah penduduk akibat urbanisasi maka makin meningkat pula kebutuhan lahan, dan pada lahan yang terbatas, beberapa responden memaksimalkan penggunan bangunan hunian mereka. Terdapat beberapa bangunan yang dihuni lebih dari 1 kepala keluarga (RT 03 RW 05). Kondisi ini menjadikan hunian kumuh dan tidak sehat karena tidak sesuai standar kebutuhan ruang hunian/luas lantai minimum hunian 5-9 m2 (SNI 031733-2004).

\section{Keterbatasan lahan}

Maraknya hunian ilegal di pesisir Padarni juga dipengaruhi oleh terbatasnya lahan. Urbanisasi penduduk/pekerja merupakan potensi bagi kelurahan Padarni, namun ketersediaan lahan yang ada berbanding terbalik dengan peningkatan penduduk. Akibatnya pembangunan hunian ilegal marak di kawasan pesisir, Penggunaan lahan di kawasan pesisir kelurahan Padarni berdasarkan analisis daya dukung sudah melebihi batas daya dukung dikarenakan kepadatan penduduk yang tinggi. Akibatnya, banyak penduduk yang menempati /membangun hunian di perairan/atas air. Hadisabari Yunus (2008) mengungkapkan bahwa pemadatan rumah mukim merupakan dampak ikutan yang selalu menyertai gejala pertambahan jumlah penduduk. Densifikasi bangunan mukim terjadi karena adanya proses pengisian kedalam, yaitu bertambahnya bangunanbangunan rumah mukim didalan lahan permukiman yang dibangun di antara bangunan-bangunan yang sudah ada. Proses ini terjadi di dalam lahan 
permukiman lama dengan tatanan bangunan yang tidak teratur ditinjau dari segi arsitektural, ukurannya dan tata letaknya.

\section{Kemudahan akses}

Dari lokasi kerja responden 86 reponden bekerja di sekitar padarni, yang berarti tempat bekerja tidak jauh dari lokasi hunian. Begitu juga dengan warga nelayan yang merasa lebih mudah menjual hasil tangkapan karena dekat dengan Pasar ikan. Kemudahan ini karena lokasi Kelurahan Padarni yang strategis, dekat dengan pusat ekonomi, kemudahan transportasi lokal dan antar pulau, hingga ketersediaan sarana pendukung (pelayanan) transportasi lainnya seperti taksi, ojek dan lainnya.

\section{Sarana prasarana dasar permukiman}

Kawasan pesisir Padarni masih merasakan kurangnya pemenuhan kebutuhan air minum dan air bersih, kelayakan jalan lingkungan, jaringan drainase dan sanitasi serta ruang publik atau ruang terbuka. Ada beberapa prasarana dan sarana umum (PSU) yang dibangun pemerintah dan bantuan yang konsisten dari pemerintah, namun karena minimnya pengelolaan sarana dan prasarana lingkungan permukiman yang baik, kemampuan dan kapasitas serta kesadaran masyarakat juga rendah/terbatas, banyak terjadi penurunan kualitas PSU dan bahkan tidak dapat digunakan lagi.

\section{Lemahnya Penerapan Kebijakan pemerintah Daerah}

Meskipun ada peraturan terkait arahan pemanfaatan ruang dan ketentuan pendirian bangunan serta beberapa program penataan, kawasan pesisir Padarni masih berada dalam kondisi kumuh. Kurang tegasnya pengendalian, penerapan kebijakan, minimnya pencegahan serta kurang sosialisasi yang melibatkan masyarakat serta kajian penanganan kawasan menjadikan peraturan dan program berjalan kurang optimal.

Menurut Agus Sadana (Sadana, 2014), berkembangnya permukiman kumuh antara lain disebabkan oleh pertumbuhan kota yang tinggi, yang tidak diimbangi oleh tingkat pendapatan yang cukup dan keterlambatan pemerintah kota dalam merencanakan dan membangun prasarana kota pada daerah perkembangan permukiman baru.

\section{Arahan Penataan Kawasan Pesisir}

kegiatan penataan kawasan kumuh harus dilakukan secara menyeluruh tidak hanya aspek fisik binaan saja namun juga aspek nonfisik sampai dengan dukungan pemerintah yang konsisten. Dasar pertimbangan arahan penataan kawasan pesisir Kelurahan Padarni adalah sebagai berikut:

Arahan pola ruang, program penataan dan peraturan terkait, Kebutuhan lahan dan status/hak kepemilikan tanah, Aksesibiltas, Keterbatasaan lahan \& kepadatan bangunan tinggi, Ketersediaan dan pengelolaan prasarana dasar, Pembatas perkembangan ruang pantai, Resiko bencana, Partisipasi Masyarakat, Lokasi strategis Kawasan, dan Potensi Hasil Laut.

Arahan Penataan Kawasan Permukiman Pesisir Kelurahan Padarni, Skenario penataan dibagi 3 tahapan:

A. Tahapan Kajian kebutuhan kawa-san pesisir Padarni dan pengum-pulan informasi.

Merupakan tahapan pengumpulan informasi kawasan pesisir Padarni terkait penanganan kumuh, baik untuk peningkatan kualitas kawasan maupun untuk pencegahannya.

B. Tahapan Peningkatan Kualitas Kawasan Permukiman Kumuh

Arahan peningkatan kualitas dilakukan mendukung konsep program dari Badan Perencanaan Pembangunan 
Daerah Kabupaten Manokwari yaitu pengembangan Teluk Sawaybu sebagai Waterfront City dengan tujuan perencanaan menarik minat masyarakat dan investor terhadap kawasan sebagai bagian dari kawasan eksklusif (enclave system development), menjaga keindahan alam, peningkatan kualitas hunian, menyediakan fasilitas umum, rekreasi dan kenyamanan, pengurangan resiko bencana serta mixed use developments. Peningkatan dan penguatan identitas lokal (kearifan lokal), waterfront development, penghijauan, berkarakter serta budaya lokal dan pembangunan landmark kawasan sebagai ikon (Bappeda, 2005).

C. Tahapan Pencegahan kumuh

Rumusan pencegahan penurunan kualitas lingkungan permukiman dan tumbuhnya permukiman kumuh baru yaitu:

1. Pengawasan dan pengendalian pembangunan permukiman

- Sosialiasi/Penyuluhan tentang rencana tata ruang daerah (RTRW/RDTR)

- Penyuluhan tentang persyaratan IMB, Legalitas kepemilikan tanah dan peruntukannya

- Penyuluhan tentang standar teknis pembangunan infrastruktur

- Penyuluhan tentang ldentifikasi permasalahan serta kelayakan fungsi bangunan (terutama bangunan hunian)

- Penguatan peran masyarakat dalam operasional dan pemeliharaan

- Peningkatan kepedulian mitigasi bencana melalui sosialisasi dan dukungan pembentukan sikap tanggap bencana.

2. Membangun jejaring kemitraan dengan membangun jejaring kerja sama dengan pihak lain dalam pencegahan kumuh.

3. Penguatan dan pengembangan penghidupan berkelanjutan melalui penguatan kelompok untuk pengembangan ekonomi lokal dengan basis potensipotensi lokal, khususnya bagi peningkatan pendapatan warga berpenghasilan rendah di kawasan kumuh.

4. Pembangunan dan pemeliharaan Prasarana saran umum (PSU): pelatihan pemeliharaan PSU yang memenuhi standar kelayakan teknis dan kelayakan fungsi.

5. Pembentukan kelompok tanggap dan waspada bencana serta Pelatihan penguatan kapasitas tanggap darurat dan pemeliharaan jalur-jalur evakuasi.

6. Penguatan peran pemda pada aspekaspek kekumuhan sesuai bidang masing-masing sebagai mitra masyarakat dalam pencegahan kumuh.

D. Tahapan Pengendalian Pemanfa-atan Ruang Oleh Masyarakat

Menurut Sadyohutomo (Tata Guna Tanah dan Penyerasian Tata Ruang, 2012) peran serta masyarakat merupakan syarat mutlak keefektifan upaya pengendalian pemanfaatan ruang yang bertujuan tertibnya tata ruang. Masyarakat akan merasa ikut memiliki dan bertanggung jawab terhadap tertib penataan ruang. Untuk itu diperlukan keterlibatan sejak awal perencanaan, pemanfaatan dan pengendaliannya.

\section{Desain Penataan Kawasan}

Berkonsep desain "Teluk Sawaybu Waterfront Development", dapat diartikan sebagai kota yang memanfaatkan kawasan pantai sebagai pengembangan (Prakoso, 2017) yang terbagi menjadi dua area pengembangan utama yaitu kawasan komersil dan permukiman serta fasiltas penunjang. 


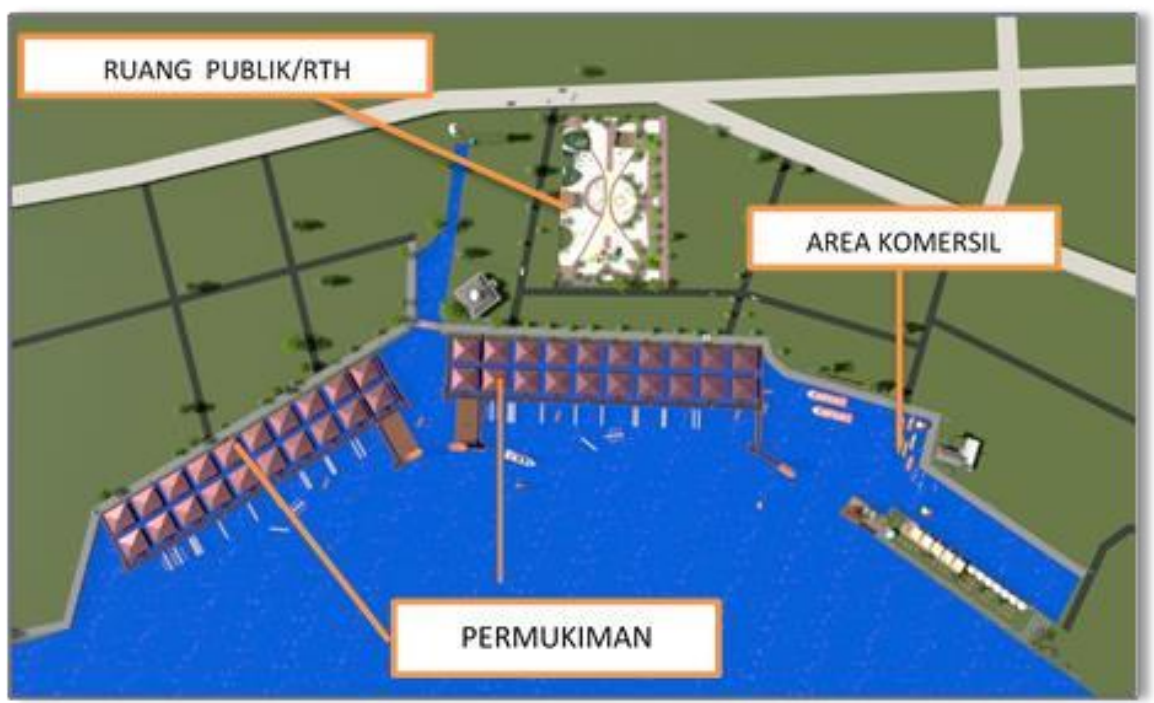

Gambar 1. Desain Kawasan Permukiman Nelayan

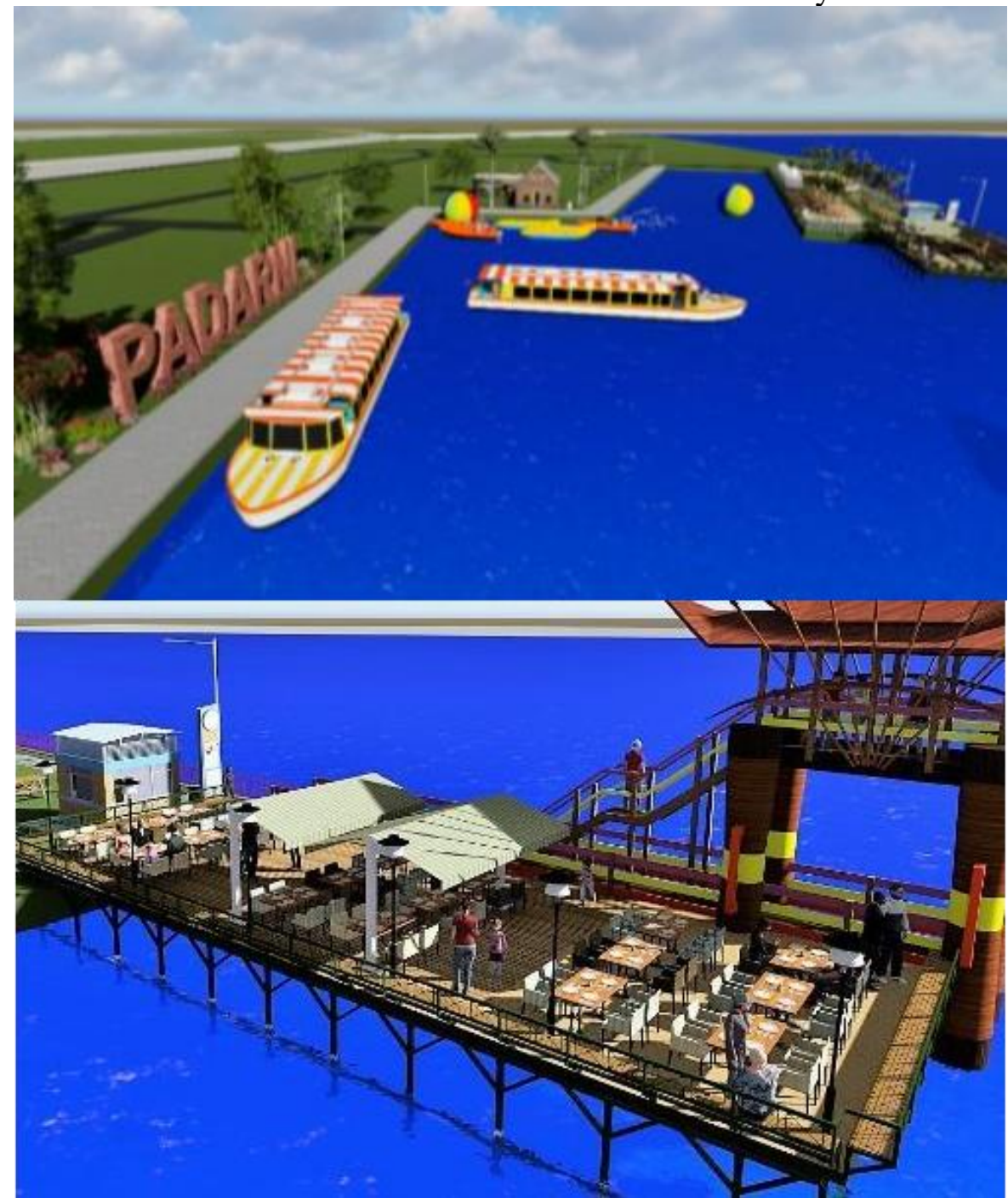

Gambar 2. Desain Area Komersil Wisata air (Water Sport dan pusat makanan) 


\section{A. Kawasan Komersial (Commercial Waterfront) \\ Kriteria pokok pengembangan} kawasan komersial di kota pantai adalah:

a. Harus mampu menarik pengunjung yang akan memanfaatkan potensi kawasan pantai sebagai tempat bekerja, belanja maupun rekreasi (wisata)

b. Kegiatan diciptakan tetap menarik dan nyaman untuk dikunjungi (dinamis)

c. Bangunan harus mencirikan keunikan budaya setempat dan merupakan sarana bersosialisasi dan berusaha (komersial)

d. Mempertahankan keberadaan golongan ekonomi lemah melalui pemberian subsidi.

e. Keindahan bentuk fisik (profil tepi pantai) kawasan pantai diangkat sebagai faktor penarik bagi kegiatan ekonomi, sosialbudaya, dan lain-lain.

Area komersil merupakan area seluas 1 hektar yang ditata dan dikembangkan dengan tujuan komersil yaitu untuk water sport, wisata city view (Bappeda, 2005) serta perdagangan olahan hasil laut nelayan dan masyarakat lokal. Dengan ikon watch tower/menara pantau berciri khas khusus yang dijadikan sebagai landmark kawasan.

Bangunan Menara Pantau terinspirasi dari bentuk rumah tradisional Biak Rumsram dengan model atap berundak, seperti model bangunan kantor gubernur dan Mapolda Papua Barat, bangunan ditopang empat pilar beton berbentuk tifa dengan motif ukiran khas Papua, dihiasi busur dan anak panah pada sisi bangunan. Menara ini juga berfungsi sebagai gerbang kawasan.

Pujasera dan Cafe Terapung, berada di area watersport dibangun dengan model teras cafe berkonsep pujasera khusus makanan. Dimaksudkan untuk mendukung pengembangan olahan hasil perikanan hasil buatan warga sekitar Padarni, seperti Ikan asar, Roti, lauk pauk dan sayur.

Arena Ketangkasan dan hiburan, merupakan area pemainan ketangkasan dengan atraksi seperti jet ski, banana boat, sepeda air, balon air, penyewaan pancing dan layangan, serta tur pemandangan kota menggunakan bis laut.

\section{B. Kawasan Permukiman (Residen- tial Waterfront)}

Kriteria pokok pengembangan kawasan permukiman di kota pantai adalah:
a. Perlu keselarasan pembangunan untuk kepentingan pribadi (private) dan umum.
b. Perlu memperhatikan tata air, buda- ya lokal serta kepentingan umum.
c. Pengembangan kawasan permu- kiman dapat dibedakan atas kawa- san permukiman penduduk asli dan kawasan permukiman baru.

d. Pada permukiman/perumahan nelayan harus dilakukan upaya penataan dan perbaikan untuk meningkatkan kualitas lingku-ngan dan kawasan. Penempatan perumahan nelayan baru hendaknya disesuaikan dengan potensi sumber daya sekitar dan "mar-ket" hasil budidaya perikanan.

e. Program pemanfaatan kawasan yang dapat diterapkan untuk kawasan permukiman penduduk asli (lama) antara lain: revitalisasi /penataan bangunan, penye-diaan utilitas, penanganan sarana air bersih, air limbah dan persampahan, penyediaan dermaga perahu, serta pemeliharaan drainase.

f. Program pemanfaatan kawasan yang dapat diterapkan untuk kawasan permukiman baru antara lain: penataan bangunan dengan memberi ruang untuk public access ke badan air, pengaturan pengambilan air 
tanah, rekla-masi, pengaturan batas sempadan dari badan air, program

penghi-jauan sempadan, dan lainlain.

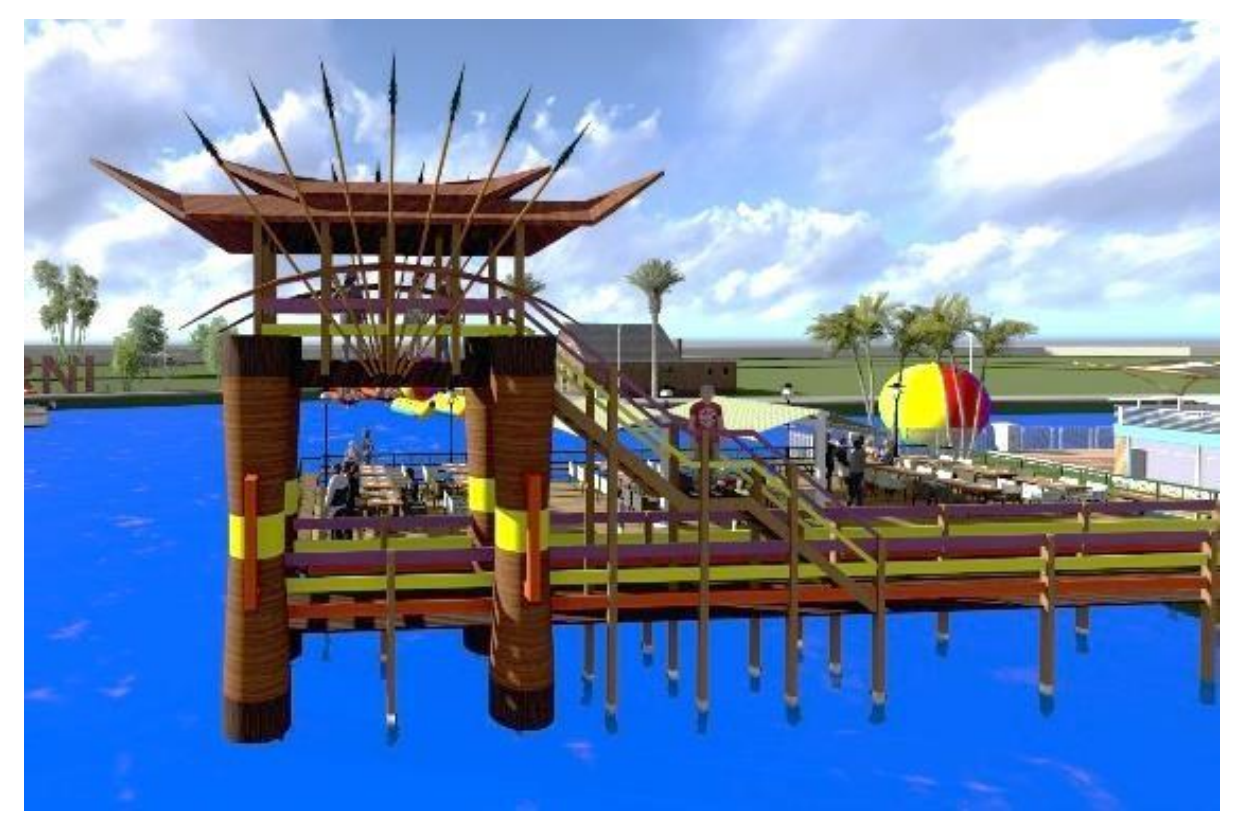

Gambar 3. Desain Menara pantau sebagai ikon kawasan Padarni
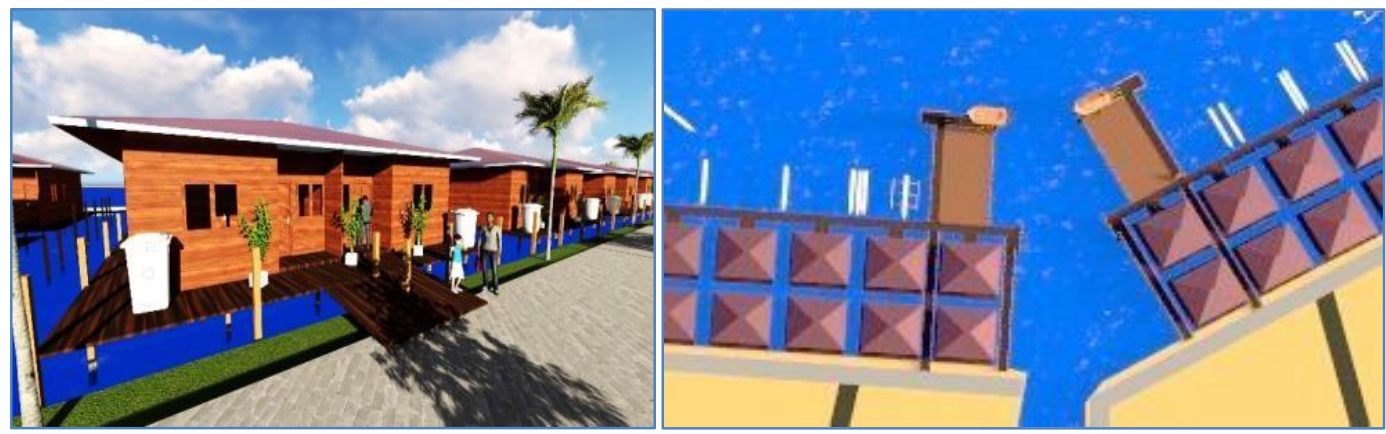

Gambar 4. Desain Bangunan Hunian dan Jarak antar bangunan meminimalisir resiko kebakaran serta untuk sirkulasi dan kenyamanan penghuni.

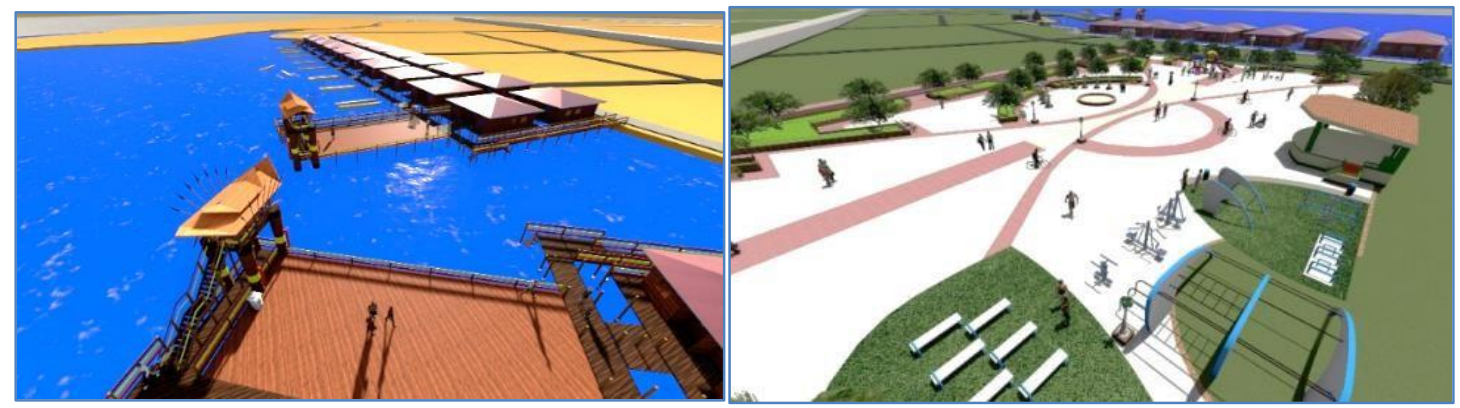

Gambar 5. Desain ruang publik serba guna dan Ruang Terbuka serbaguna

Area Permukiman merupakan area khusus permukiman dengan sifat bangunan non permanen dan dibangun sesuai standar kelayakan bangunan.
Bangunan type 45 dengan model berpasangan disesuaikan dengan karakteristik penduduk dan tingkat kebutuhan (Simorangkir, 2018). Bangunan dikhususkan 
untuk nelayan dengan arah hadap bangunan ke laut dan darat dengan 2 jenis parkiran kapal yaitu yang terlindungi (di dalam dermaga) dan tidak terlindungi (di luar) untuk akses yang lebih cepat atau untuk kapal nelayan berbadan besar. Pengembangan masa bangunan tidak diperbolehkan dengan batasan jembatan titian terluar dan luar talud dari kawasan.

Dengan luas kurang lebih 1,2 hektar, kawasan permukiman didesain mengikuti garis pantai yang terbagi menjadi 2 blok hunian total 80 rumah (1 blok terdapat 40 rumah), dengan masing masing blok dibangun hunian model berpasangan. Untuk akses kawasan diarahkan untuk ditata menjadi lurus menghubungkan jalan utama lebar jalan lingkungan minimal 3 meter dan jalan jerambah (titian) 2 meter dengan pembatas, serta pembangunan jalan inspeksi yang juga berfungsi sebagai jalan lingkungan di sepanjang talud.

\section{Fasilitas dan Utilitas}

Terdapat dua open space /area terbuka, (luas: $240 \mathrm{~m} 2$ x 2) di area permukiman nelayan untuk kegiatan warga, yang dapat digunakan berbagai keperluan. Semisal memperbaiki jaring, menjemur ikan, pertemuan warga, dan bersosialisasi. Fasilitas publik lainnya berupa taman atau ruang terbuka multi fungsi, seluas $5.000 \mathrm{~m} 2$ sebagai tempat bersosialisasi, bermain anak, tempat berolah raga, penyelenggaraan kegiatan, titik kumpul dan tempat evakuasi untuk keadaan darurat.

Untuk penerangan jalan lingkungan digunakan energi ramah lingkungan yaitu lampu Light Emitting Diode (LED) bertenaga surya, sedang persampahan menggunakan tempat sampah portable agar memudahkan pengumpulan sampah menuju kekendaraan pengangkut atau ketempat penampungan sementara.

Sistem Pengelolaan Air Limbah Domestik (SPAL) setempat berkapasitas $760 \mathrm{~m} 3(190 \mathrm{~m} 3 \times$ x 4) berada di area taman untuk memudahkan pengangkutan serta pemeliharaan/kontrol dimana standar kebutuhan 200 rumah $180 \mathrm{~m} 3$ sesuai Pedoman SPALD-Permukiman (Iskandar, 2016). Desain Pipa Jaringan air bersih dan saluran pembuangan air limbah terletak di bawah jembatan titian/jerambah untuk penataan jaringan yang baik serta memudahkan dalam pemeliharaan. Penyelenggaraan pengelolaan air limbah domestik bertujuan untuk meningkatkan akses pelayanan air limbah domestik yang ramah lingkungan, sehingga tercapai peningkatan kualitas kehidupan masyarakat dan lingkungan yang lebih baik dan sehat (Iskandar, 2016).

\section{PENUTUP}

\section{Kesimpulan}

Dari hasil pengamatan dan analisis dapat diambil beberapa kesimpulan yaitu:

1. Kawasan pesisir Padarni merupakan dataran rendah yang penggunaan lahannya didominasi hunian dengan pola permukiman linier mengikuti garis pantai dan jalan. Penduduknya bekerja sebagai nelayan dan sektor swasta dan merupakan pendatang dari beberapa daerah diantaranya dari Buton, Biak, Wondama dan lainnya. Memiliki rata-rata kepadatan penduduk tinggi (rata-rata $280 \mathrm{jiwa/ha)} \mathrm{dan} \mathrm{luas}$ hunian rata-rata di atas $51 \mathrm{~m} 2$ (73\%).

2. Kawasan pesisir Padarni memi-liki daya dukung lahan yang terbatas namun memiliki potensi sumberdaya manusia dan pengembangan 
sektor wisata. Karakteristik penduduknya masih membawa sifat dan perilaku ke-hidupan daerah asal, kondisi fisik bangunan dan lingkungan kurang baik (bangunan non permanen) dan tidak beraturan, kerapatan bangunan dan penduduk tinggi serta merupakan daerah yang beresiko bencana gempa, suna-mi, dan kebakaran.

3. Bertipologi kawasan kumuh di atas air, 7,8 Ha kawasan pesisir Padarni termasuk dalam kategori kumuh berat dan 8,7 Ha kumuh sedang. Perubahan penggunaan lahan sebagian besar dimotivasi oleh aspek sosial budaya (kekerabatan dan kesukuan) dengan luas penyimpangan lahan ter-hadap tata ruang mencapai 8,17 Ha.

4. Penyebab kondisi kekumuhan kawasan pesisir Padarni adalah karakteristik sosial budaya, urbanisasi, keterbatasan lahan, kemudahan akses, prasarana dan sara-na, serta kurang tegasnya kebija-kan pemerintah.

5. Arahan Peningkatan kualitas kawasan permukiman kumuh pesi-sir Padarni terbagi menjadi tiga tahapan utama yaitu kajian kebu-tuhan kawasan dan pengumpulan informasi, peningkatan kualitas kawasan permukiman kumuh dan pencegahan kumuh.

6. Desain penataan kawasan Permukiman kumuh pesisir Padarni diarahkan untuk menjadikan kawasan pesisir Padarni sebagai kawasan permukiman dan komersial dalam Konsep Teluk Sawaybu-Waterfront Development.

\section{Saran}

1. Upaya penanganan kawasan kumuh memerlukan kerjasama yang terpa$\mathrm{du}$, intensif dan konsisten dari berbagai sektor (multiaspek) oleh tiga pelaku utama yaitu, pemerintah, masya-rakat dan pihak ketiga/mitra. Agar penanganan kumuh tidak hanya berhenti dipenataan kawasan saja namun juga memperta-hankan kondisi tersebut (tertatanya kawasan) sekaligus meningkatkan potensi-potensi lainnya dari kawasan.

2. Peningkatan kualitas kawasan kumuh dapat dilakukan secara bertahap sesuai kemampuan dae-rah didasarkan skala prioritas penanganan kawasan yang telah dinilai oleh pemerintah daerah. Perlunya mencari alternatif sumber pendanaan program diluar APBD, seperti kemitraan dengan swasta terutama kontraktor, pengembang perumahan, dan perusahaan.

\section{DAFTAR PUSTAKA}

Adisasmita, R. (2006). Pembangunan Pedesaaan dan Perkotaan, Edisi. Yogyakarta: Graha ilmu.

Ahmad, N. (2006). Manajemen Perkotaan. Yogyakarta: Sinergi Publishing.

Arikunto, S. (2006). Prosedur Penelitian: Suatu pendekatan Praktik. Jakarta: PT. Rineka Cipta.

Bappeda. (2005). Teluk Sawaybu Waterfront Development. Manokwari: Bappeda Kabupaten Manokwari.

Baun, P. I. (2008). Thesis; Kajian Pengembangan pemanfaatan ruang terbangun dikawasan pesisir kota Kupang. Semarang: Universitas Diponegoro.

Budianto, H. T. (2001). Urbanisasi dalam interaksi keruangan kota. 
Jakarta: Universitas Indonesia Press.

Budiharjo, E. (2009). Perumahan dan Permukiman di Indonesia. Bandung: Alumni.

Djumiko. (2010). Identifikasi Ciri-Ciri Perumahan Di Kawasan Pesisir Kasus Kelurahan Sambuli Dan Todonggeu Kecamatan Abeli Kota Kendari. Jurnal Teknik Sipil dan Arsitektur Vol 7, No 11, 11.

Eko, T. (2012). Perubahan Penggunaan Lahan dan Kesesuaiannya Terhadap RDTR di Wilayah PeriUrban (Studi Kasus: Kecamatan Mlati). Jurnal Perencanaan Wilayah dan kota Vol 8, No 4 (2012): UNDIP Semarang, 4.

Firmansyah, F. (2013). Pengindraan Jauh Untuk Evaluasi Penggunaan Lahan. Seminar Nssional Pendayagunaan Informasi Geospasial (hal. 164-169). Surabaya : FTSP-ITS.

Haryadi dan B Setyawan. (2000). Arsitektur Lingkungan dan Perilaku Teori, Metodologi dan Aplikasi. Jakarta: Proyek Pengembangan Pusat Studi Lingkungan Direktorat Pendidikan Tinggi Departement Pendidikan \& Kebudayaan.

Jayadinata, J. T. (1999). Tata Guna Tanah dalam Perencanaan. Pedesaan Perkotaan dan Wilayah. Bandung: Institut Teknologi Bandung.

Kamus Tata Ruang edisi I. Jakarta: Departemen Pekerjaan Umum. KEMENPUPERA. (2016). Laporan Kinerja Direktorat Jendral
Cipta Karya. Jakarta: KEMENPUPERA.

Kodoatie, R. J. (2010). Tata Ruang Air. Yogyakarta: Andi Offset.

Koester, R. H. (2001). Dimensi Keruangan Kota. akarta.: Universitas.

Koeswahyono., H. d. (2008). Aspek Kebijaksanaan Hukum Penatagunaan Tanah dan Penataan Ruang. Jakarta : Sinar Grafika.

Koeswahyono., H. d. (2008). Aspek Kebijaksanaan Hukum Penatagunaan Tanah dan Penataan Ruang. Jakarta: Sinar Grafika.

KOTAKU. (2018). Rencana Tindak Penataan Lingkungan Permukiman. Manokwari: Kelurahan Padarni.

Kuswartojo, T. (2005). Perumahan dan permukiman di Indonesia. ITB: Bandung.

Peraturan Daerah Kab Manokwari No 10 tahun 2003 tentang Bangunan Gedung. Manokwari: Pemerintah Kab. Manokwari.

Kabupaten Manokwari Dalam Angka Tahun 2017. Manokwari: BPS.

Mardhani, H. (2012). Penanganan Kawasan permukiman kumuh tepi sungai Barito Puruk Cahu. Jurnal Perspektif Arsitektur Volume 7 / No.2, Desember 2012, 27.

Muchsin, I. K. (2008). Aspek kebijaksanaan, hukum penatagunaan tanah \& penataan ruang. Jakarta: Sinar Grafika. 
Mulyono, S. (2006). Penatagunaan Tanah sebagai Sub Sistem dari Penataan Ruang. Yoyakarta: Aditya media,.

Mulyono, S. (2012). Tata Guna Tanah dan Penyerasian Tata Ruang. Surabaya.: Pustaka Pelajar.

Otto, S. (1991). Ekologi, lingkungan hidup dan pembangunan. Bandung: Djembatan.

Pamekas, R. (2013). Pembangunan dan pengelolaan infrastruktur kawasan permukiman. Bandung: Dunia Pustaka Jaya.

Prakoso, A. A. (2017). Arahan pengembangan Kawasan wisata sungai Musi Kota Palembang. Jurnal Arsitektur dan Perencanaan, Vol. 1, No. 1, Desember 2017, 1-10. Diakses dari https://ejournal. unisayogya.ac.id.

Prasetyo, B. \&. (2006). Metode penelitian kuantitatif: teori dan aplikasi. Jakarta: Raja Grafindo Persada.

Permen PU No.29 Tahun 2006 Tentang pedoman persyaratan teknis bangunan gedung.

Peraturan Pemerintah No. 15 Tahun 2010 Tentang Penataan Ruang.

Peraturan Pemerintah Indonesia No. 66. Tentang Kesehatan Lingkungan.

PermenPUPERA Nomor 25 Tahun 2014 Tentang Penyelenggaraan data dan informasi Geospasial Infrastruktur Bidang Pekerjaan Umum dan Perumahan Rakyat.

Peraturan Pemerintah No. 36 tahun 2005 tentang peraturan pelaksanaan UU
No. 28/2002 tentang bangunan gedung.

Peraturan Menteri Pekerjaan Umum No. 2 Tahun 2016 Tentang Peningkatan Kualitas Terhadap Perumahan Kumuh dan Permukiman Kumuh.

Profil Kelurahan Padarni Tahun 2016. Manokwari: Kelurahan Padarni.

Ridwan, M. (2017). Skripsi; Arahan penataan kawasan Tepi Air (Water Front) Sungai Musi Sebagai Kawasan Pariwisata. Bandung: universitas pasundan. Diakses dari http://repository.unpas.ac.id/2900 4/

Rokhmin Dahuri . (2001). Pengelolaan Sumber Daya Wilayah Pesisir dan Lautan Secara Terpadu. Bogor: Pradnya Paramita. RTRW Kab. Manokwari Tahun 2013-2033.

Manokwari: Bappeda Kab Manokwari. Sadana, A. (2014). Perencanaan Kawasan Perumahan. Yogyakarta: Graha Ilmu.

Samadhi, N. (2004). Perilaku dan Pola Ruang. Malang: LPPM TPWK ITN Malang. Simorangkir, E. (2018, April 2). https://finance. detik.com/properti/d-3948964/ pupr-tambah-kriteria-rumahlayak-huni-ke-tipe-45.Diakses dari detik.com.

SNI 03-1733-2004. Tata cara perencanaan lingkungan perumahan perkotaan, 19-20.

Sugiharto E, S. I. (2013. ). Studi Tingkat Kesejahteraan Masyarakat Nelayan di Kampung Gurimbang Kecamatan Sambaliung Kabupa- 
ten Riau. Jurnal Ilmu Perikanan Tropis, 50-62.

Sugiyono. (2010). Metode Penelitian Kuantitatif Kualitatif dan R\&D. Bandung: CV Alfabeta.

Suryanto. (2009). Thesis: Daya dukung lingkungan daerah aliran sungai untuk pengembangan kawasan permukiman. Semarang: Universitas Diponegoro.

Sutedi, A. (2011). Hukum Perizinan Dalam Sektor Pelayanan Publik. Jakarta: Sinar Grafika. Sistem Pengelolaan Air Limbah Domestik terpusat Skala Lingkungan. Jakarta: Ditjen Cipta Karya-DIt PPLP.

Trigus Eko, S. R. (2012). Perubahan Penggunaan Lahan dan Kesesuaiannya terhadap RDTR di Wilayah Peri-Urban Studi Kasus: Kecamatan Mlati. Jurnal Pembangunan Wilayah dan Kota, 331.

Ucok Heriady Ridwan, S. R. (2012). Kualitas Lingkungan Permukiman Masyarakat Suku Bajo di Daerah yang Berkarakter Pinggiran Kota dan Daerah Berkarakter Pedesaan di Kabupaten Muna. Jurnal Pembangunan Wilayah Dan Kota Vol. 8, 118-125.

Undang-undang No. 27 tentang Pengelolaan Wilayah Pesisir dan PulauPulau Kecil. Undang-Undang No. 1 Tentang Perumahan dan Kawasan Permukiman.
Undang Undang No. 26 tahun 2007 Tentang Penataan Ruang .

Utami, W. (2012). Skripsi : Keterkaitan Pola Pergerakan Transportasi Pada Jaringan Jalan Terhadap Perkembangan Wilayah di Kecamatan Delanggu Kabupaten Klaten. Semarang: Universitas Sebelas Maret.

Wiwik Wahidah Osman, A. P. (2013). Konsep Tata Bangunan pada Permukiman Padat di Kawasan Pesisir Pantai, Studi Kelurahan Cambaya Kecamatan Ujung Tanah Kota Makassar. Temu Ilmiah Ikatan Peneliti Lingkungan Binaan Indonesia (hal. F-42). Makasar: Fakultas Teknik Universitas Hasanuddin,.

Wiwik, W. (2011). Studi Potensi Lingkungan Pemukiman Kumuh di Kampung Kota. Jurnal Jurusan Arsitektur FTSP-ITATS, 29-33.

Yunus, H. S. (2002). Struktur Tata Ruang Kota. Yogyakarta: Pustaka Pelajar.

Yunus, H. S. (2008). Dinamika Wilayah Periurban. Yogyakarta: Pustaka Pelajar.

Zahnd, M. (2006). Perancangan kota terpadu, Teori Perancangan Kota dan Penerapannya. Edisi revisi. Yogyakarta.: Kanisius.

Zulkaidi, D. (1999). Pemahaman Perubahan Pemanfaatan Lahan Kota Sebagai Dasar bagi Kebijakan Penanganannya. Jurnal PWK., 1. 